
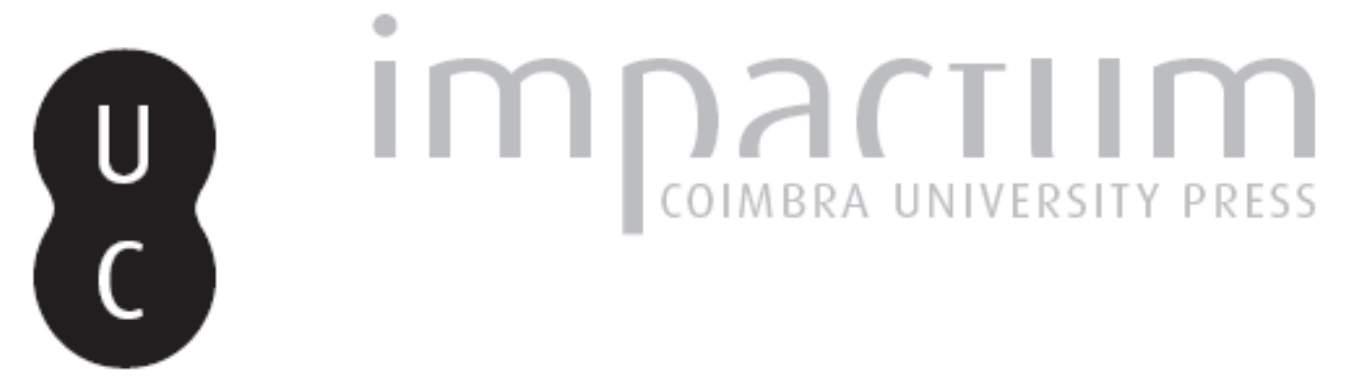

\title{
Portuguese complementary education in the United Kingdom
}

\section{Autor(es): $\quad$ Marques, Pedro}

Publicado por: Imprensa da Universidade de Coimbra

URL persistente:

URI:http://hdl.handle.net/10316.2/43245

DOI:

DOI:https://doi.org/10.14195/0870-4147_48_9

Accessed : $\quad$ 26-Apr-2023 12:20:25

A navegação consulta e descarregamento dos títulos inseridos nas Bibliotecas Digitais UC Digitalis, UC Pombalina e UC Impactum, pressupõem a aceitação plena e sem reservas dos Termos e Condições de Uso destas Bibliotecas Digitais, disponíveis em https://digitalis.uc.pt/pt-pt/termos.

Conforme exposto nos referidos Termos e Condições de Uso, o descarregamento de títulos de acesso restrito requer uma licença válida de autorização devendo o utilizador aceder ao(s) documento(s) a partir de um endereço de IP da instituição detentora da supramencionada licença.

Ao utilizador é apenas permitido o descarregamento para uso pessoal, pelo que o emprego do(s) título(s) descarregado(s) para outro fim, designadamente comercial, carece de autorização do respetivo autor ou editor da obra.

Na medida em que todas as obras da UC Digitalis se encontram protegidas pelo Código do Direito de Autor e Direitos Conexos e demais legislação aplicável, toda a cópia, parcial ou total, deste documento, nos casos em que é legalmente admitida, deverá conter ou fazer-se acompanhar por este aviso.

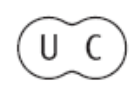




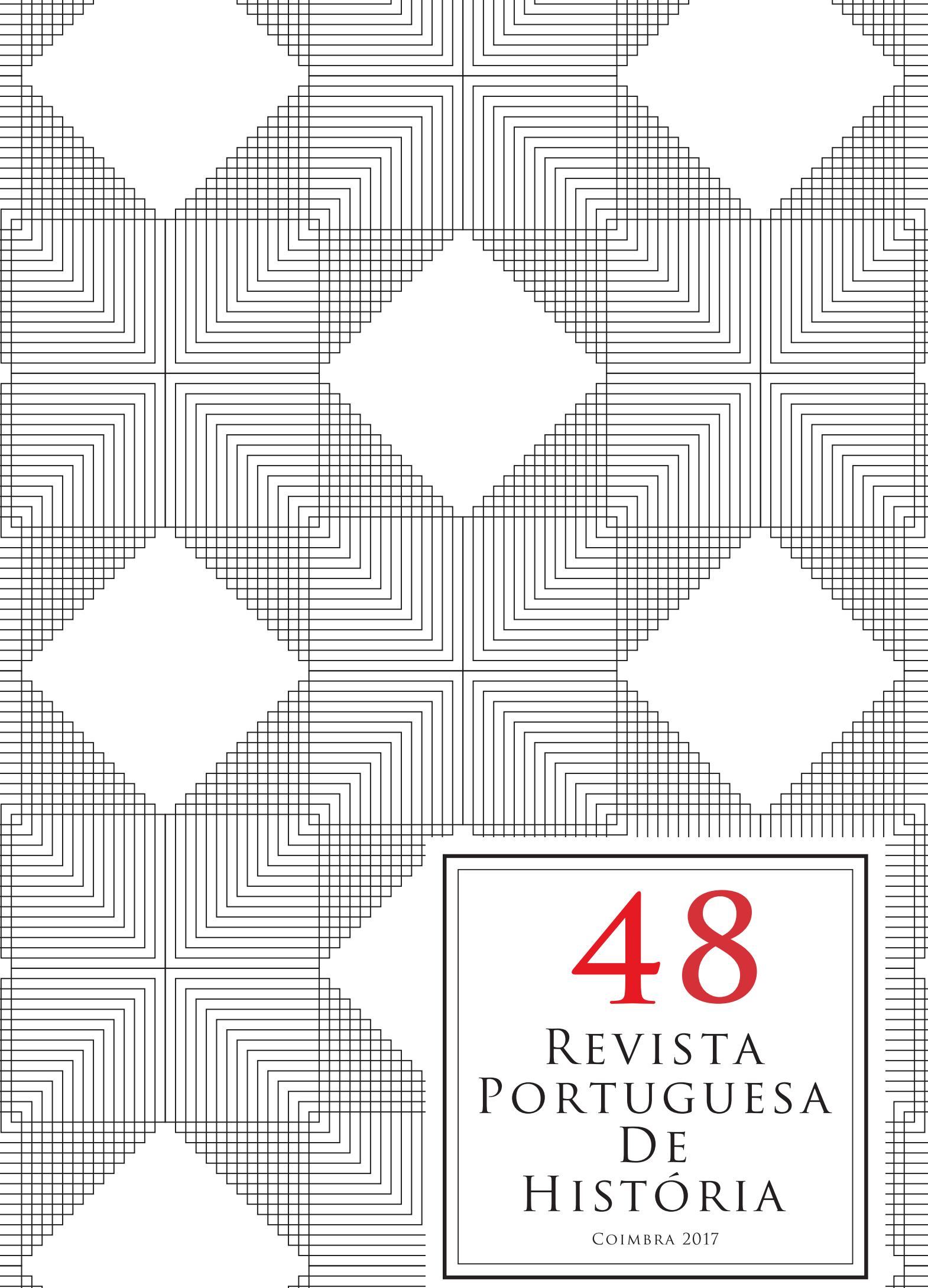




\title{
Portuguese complementary education in the United Kingdom
}

\author{
O Ensino Português no Estrangeiro no Reino Unido
}

\author{
Pedro Marques \\ Instituto Camões \\ pedro.marques@camoes.mne.pt \\ Texto recebido em/Text submitted on: 16/11/2016 \\ Texto aprovado em/Text approved on: 10/05/2017
}

Abstract:

One of the most visible manifestations of Portuguese language education in the United Kingdom, complementary schooling (Ensino Português no Estrangeiro) is the result of Portuguese immigration from the 1960 s to the present day, magnified by the intake of Brazilian migrants in the 1990s and 2000s. Heritage language classes were a grassroots initiative of parents and immigrant associations with a strong component of language maintenance. Just before the 1974 democratic revolution in Portugal, the Portuguese government took over the organisation of classes but the development of the network as a support mechanism of migrant communities happened in the post-revolutionary period. At the turn of the $21^{\text {st }}$ century, the provision of complementary classes had to adapt to new political and legislative discourses. Especially after the 2006-2009 period, when the classes came under the supervision of the Instituto Camões, Portuguese language was assigned a new role, that of an economic asset in a globalised world. Amongst the community, Portuguese language education became an investment in cultural and educational capital.

Keywords:

complementary education, heritage language, Portuguese.
Resumo:

Uma das manifestações mais visíveis do ensino da língua portuguesa no Reino Unido, o Ensino Português no Estrangeiro, resulta da imigração portuguesa entre os anos 60 do século XX e a atualidade, realidade que adquiriu uma nova expressão com a chegada de imigrantes brasileiros entre 1990 e a primeira década de 2000. As aulas de língua portuguesa nasceram como uma iniciativa de base comunitária, promovidas por pais e associações de imigrantes e marcadas por uma política de manutenção de língua. Ainda antes da revolução de 1974, o governo português assumiu a organização dos cursos, tendo a expansão da rede de apoio às comunidades diaspóricas acontecido no período pós-revolucionário. Na viragem para o século XXI, a rede teve de se adaptar a novos discursos políticos e legislativos. Especialmente após o período entre 2006 e 2009, momento em que os cursos transitaram para a tutela do Instituto Camões, a língua portuguesa adquiriu um novo papel, o de recurso económico num mundo globalizado. No seio da comunidade, a aprendizagem de português passou a ser encarada como um investimento em capital cultural e educativo.

Palavras-chave:

Ensino Português no Estrangeiro, língua de herança, português. 


\section{From post-revolutionary and multicultural optimism to scepticism}

The first complementary education ${ }^{1}$ (Ensino Português no Estrangeiro) courses in the United Kingdom (UK) were an initiative of Portuguese immigrant organisations in London. In the late 1960s, Portuguese lessons had become a significant part of community life, backed up by active parents, who recruited teachers, bought materials and books, and arranged the premises where lessons took place, normally churches and community halls ${ }^{2}$.

Just before the 1974 democratic revolution in Portugal, the Portuguese government took up the responsibility for the funding of the language provision and recruitment of instructors working with the Portuguese-speaking diaspora in a number of countries in Europe, Africa, and North America. In 1969, the government laid down the guidelines on which many primary education courses were created in Luxembourg, Germany, France, Belgium, the USA, South Africa, the Netherlands and the UK, prefiguring the geographic configuration of the present network. Aimed at those students who wanted to sit a final exam to complete their elementary education, these courses followed the national curriculum, and were meant to maintain and enhance a "spiritual" link between the migrant and the Portuguese homeland ${ }^{3}$. Language was here liable to cement an unequivocal national identity in a supposedly homogenous expatriate group ${ }^{4}$, which reflected the ambivalent attitude of Portuguese authorities towards emigration. Under the dictatorial regime, emigration was seen both as a phenomenon disruptive of the country's sovereignty and identitary fabric, and

${ }^{1}$ I use the term complementary to designate language schooling set up by minority linguistic communities (Vally Lytra and Peter Martin, "Introduction", in Vally Lytra and Peter Martin (ed.), Sites of Multilingualism: Complementary Schools in Britain Today, Stoke on Trent and Sterling, Trentham Books, 2010, p. xi-xx). The word signals the positive role of this kind of language education in the academic and personal lives of those who attend complementary schools (see Angela Creese, et al., "Multicultural, Heritage and Learner Identities in Complementary Schools", Language and Education, 20:1, 2006, p. 23-43). I use heritage and minority languages interchangeably but I shall signpost the use of heritage as correlative of a language maintenance policy.

${ }^{2}$ Olga Barradas, “'A disappearing act': Portuguese Students - Social Inclusion and Academic Attainment" in Guida de Abreu, Tony Cline and Hanna Lambert (ed.), The education of Portuguese children in Britain: insights from research and practice in England and overseas, Luton, Department of Psychology, University of Luton, p. 32-50.

${ }^{3}$ Ministério da Educação Nacional, "Decreto-lei 48944, de 28 de Março", in Diário do Governo, n. ${ }^{\circ} 74 / 1969$, Série I de 1969-03-28, Lisboa, Imprensa Nacional de Lisboa.

${ }^{4}$ Jane Beswick and Mark Dinneen, "Introduction: The Portuguese-Speaking Diaspora in Great Britain and Ireland”, Portuguese Studies, 26:1 (2010), p. 5-9. 
an unavoidable economic and social outlet, if one was to consider the economic deprivation afflicting a large proportion of the population ${ }^{5}$.

The expansion of both the network and the scope of provision would happen in the post-revolutionary period. Created in 1977, the legal apparatus issued by the new democratic regime had a two-fold aim: to promote the overall educational achievement of Portuguese migrants abroad (namely by securing full access to foreign school systems and the mutual recognition of qualifications), and to facilitate the access to Portuguese language education. The support was to be achieved primarily through the introduction of Portuguese as a subject in foreign curricula, or, as an alternative, through the creation of complementary language courses in countries with a sizeable diasporic community ${ }^{6}$. The 1977 decree, while still adopting a rather restrictive concept of cultural heritage, understood the access to Portuguese language education as a civil right, and acknowledged the migrants' need to fully access the school system of the host country. It also opened up the possibility of creating customised curricula and learning materials, which suggested a willingness to acknowledge the different sociocultural circumstances of specific communities.

The first courses opened in 1972, mainly in France and Germany, as these destinations accounted for more than $50 \%$ of Portuguese migration between the 1950 s and $1980 \mathrm{~s}^{7}$. In the $60 \mathrm{~s}$ and early $70 \mathrm{~s}$, London was not a major destination for economic migrants, but there was a small community of political expatriates ${ }^{8}$ and people working in the cleaning, hospitality and catering industries ${ }^{9}$. In 1975, the Portuguese community in London was estimated to be 4,000 and the intake of migrants was reported to slow down after this date ${ }^{10}$. The result was a predominantly adult community until the mid-1980s, when there were around

\footnotetext{
${ }^{5}$ Victor Pereira, "Ineficiência, fragilização e duplicidade. O Velho Estado Novo perante a emigração para França (1960-1968)", Ler história, 59 (2009), p. 43-68.

${ }^{6}$ Assembleia da República. "Lei 74/77 de 28 de Setembro: Língua e cultura portuguesas no estrangeiro", in Diário da República, n. ${ }^{\circ}$ 225/1977, Série I de 1977-09-28, Lisboa, Imprensa Nacional-Casa da Moeda.

${ }^{7}$ Maria Ioannis Baganha, "As correntes emigratórias portuguesas no século XX e o seu impacto na economia nacional”, Análise Social, XXIX: 128 (1994), p. 959-980.

${ }^{8}$ Maria Amélia Estrela, Rosa Starr and Maria Lúmen Rodrigues, “The Portuguese Education Department in the United Kingdom", in Guida de Abreu, Tony Cline and Hanna Lambert (ed.), The education of Portuguese children in Britain..., cit., p. 198-216.

${ }^{9}$ Paula Santarita and Marilyn Martin-Jones, "The Portuguese speech community”, in Safder Alladina and Viv Edwards, Multilingualism in the British Isles, Vol. 1: The older mother tongues and Europe, London and New York, Longman, 1991, p. 231.

${ }^{10}$ Olga Barradas, Portuguese students in London Schools: patterns of participation in community language classes and patterns of educational achievement, $\mathrm{PhD}$, Goldsmiths College/ University of London, 2004, p. 26.
} 
1,800 Portuguese-speaking school children ${ }^{11}$. Notwithstanding, the first teachers assigned to work with the community in London were recruited in 1973, still within the framework of the $1969 \mathrm{law}^{12}$. In the academic year 1974/1975, there were five teachers running ten courses, and in 1976 the Ministry of Education appointed the first person to supervise the operations in the $\mathrm{UK}^{13}$.

There was an institutional optimism in the 1970s. In the UK, the $A$ Language for Life report recommended that schools should provide a sympathetic link between the migrants' background and the British culture, while encouraging students to maintain their first language throughout their education ${ }^{14}$. The principle of free movement of workers in the European Economic Community $(\text { EEC })^{15}$ motivated a 1974 European resolution that advocated a close cooperation between host institutions and country of origin to provide education to migrant children, and a second 1977 directive that gave European Economic Community (EEC) members a five-year timeframe to offer provision in first language learning for migrants ${ }^{16}$. The UK, despite some hostility from education professionals and the government ${ }^{17}$, responded to the European directives with initiatives such as the Linguistic Minorities Project (1979-1983), which aimed at giving visibility to the multilingual reality of the UK, highlighting the potentiality of a bilingual education ${ }^{18}$. That same decade, the Inner London

${ }^{11}$ Paula Santarita and Marilyn Martin-Jones, "The Portuguese speech community”, cit., p. 231.

${ }^{12}$ Ministério dos Negócios Estrangeiros e da Educação Nacional, "Portaria 784/73, de 12 de Novembro", in Diário do Governo, n. ${ }^{\circ}$ 264/1973, Série I de 1973-11-12, Lisboa, Imprensa Nacional de Lisboa.

${ }^{13}$ Maria Amélia Estrela, Rosa Starr and Maria Lúmen Rodrigues, “The Portuguese Education Department in the United Kingdom”, cit., p. 199.

${ }^{14}$ Allan Bullock, A Language for Life, Report of the Committee of Enquiry appointed by the Secretary of State for Education and Science under the Chairmanship of Sir Alan Bullock F.B.A., London, Department of Education and Science, 1975, p. 285-294.

${ }^{15}$ The Council of the European Communities, "Regulation (EEC) No 1612/68 of the Council of 15 October 1968 on freedom of movement for workers within the Community", I-1968(II), Official Journal of the European Communities, Brussels, The Council of the European Communities. It establishes that migrants should be admitted to education systems under the same conditions as nationals.

${ }^{16}$ The Council of the European Communities, "Council Resolution of 21 January 1974 concerning a social action programme", C 13, 12 February 1974, and "Directive 77/486 on the schooling of children of migrant workers", L 199, Volume 20, 6 August 1977, Official Journal of the European Communities, Brussels, The Council of the European Communities.

${ }^{17}$ Viv Edwards, "Language policy in multicultural Britain", in John Edwards (ed.), Linguistic minorities, policy and plurilingualism, London, Academic Press, p. 60-62.

${ }^{18}$ Linguistic Minorities Project, The Other Languages of England, London, Boston, Melbourne and Henley, Routledge and Kegan Paul, 1985, p. 376-383. 
Education Authority facilitated the use of school premises after school hours for Portuguese language classes ${ }^{19}$.

In Portugal, the optimism was partly fuelled by the post-revolutionary period. The support of emigrant communities that had been rehearsed by the previous regime was now a priority, motivated by a similar policy of language maintenance but also by a willingness to redress the political and economic conditions that motivated Portuguese emigration in the 1960s. In 1973, the Ministry of Education formally set up a division to oversee language provision abroad, which developed into an independent team in $1979^{20}$. The network expanded to more than 43,000 students in Europe by the end of the decade ${ }^{21}$, and the right to Portuguese language education abroad was consecrated in the 1986 framework law on education (and again in the 1989 amendments to the post-revolutionary constitution ${ }^{22}$ ).

However, this later institutional commitment to heritage language education was accompanied by disillusionment amongst practitioners and students, a degree of scepticism in Portugal, and a shift towards institutional monolingualism in the UK.

\section{A disappearing act: underperformance and criticism}

The first ten years of the complementary courses saw the number of students reach 1,000, and the classes extended from London to some southern coastal resort towns and the island of Jersey ${ }^{23}$. There seems to have been a steady

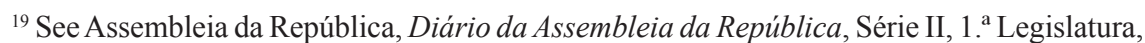
Sessão legislativa 3, Lisboa, Imprensa Nacional-Casa da Moeda, 1978 and Olga Barradas, "Linking community and mainstream schools for primary students and their teachers", in Vally Lytra and Peter Martin (ed.), Sites of multilingualism..., cit., p. 135-148.

${ }^{20}$ Ministério da Educação Nacional, "Decreto-lei 45/73, de 12 de Fevereiro", in Diário do Governo n. ${ }^{\circ}$ 36/1973, Série I de 1973-02-12, Lisboa, Imprensa Nacional-Casa da Moeda and Ministério da Educação, "Decreto-lei 541/79, de 31 de Dezembro", in Diário da República, n. ${ }^{\circ} 300 / 1979,12 .^{\circ}$ Suplemento, Série I de 1979-12-31, Lisboa, Imprensa Nacional-Casa da Moeda.

${ }^{21}$ Assembleia da República, Diário da Assembleia da República, Série II, 1. a Legislatura, Sessão legislativa 3, Lisboa, Imprensa Nacional-Casa da Moeda, 1978, p. 28-29.

${ }^{22}$ Assembleia da República, "Lei de Bases do Sistema Educativo", in Diário da República, n. ${ }^{\circ}$ 237/1986, Série I de 1986-10-14, Lisboa, Imprensa Nacional-Casa da Moeda and Assembleia da República, "Lei Constitucional 1/89, de 8 de Julho", in Diário da República, n. ${ }^{\circ}$ 155/1989, 1. ${ }^{\circ}$ Suplemento, Série I de 1989-07-08, Lisboa, Imprensa Nacional-Casa da Moeda.

${ }^{23}$ Paula Santarita and Marilyn Martin-Jones, "The Portuguese speech community", cit., p. 238. 
growth in the two-decade period between 1975 and 1999, when there were around 2,000 students and 40 teachers ${ }^{24}$. Students figures grew rapidly in the late $1980 \mathrm{~s}$, in line with the increasing number of economic migrants arriving in the UK after the 1986 to 1992 period, when Portugal became part of the EEC, and member states signed the Maastricht Treaty, which established freedom of movement and residence in the newly designated European Union (EU). Between 1981 and 1987, the number of Portuguese migrants doubled, from 30,000 to $60,000^{25}$, and during the 1990 decade there was an influx of nearly 20,000 migrants $^{26}$.

The initial optimism did not translate into a straightforward positive experience for students, teachers and parents throughout the 1980s and 1990s. The Swann report ${ }^{27}$, an inquiry into the education of children from minority groups, while supportive of a multicultural society, was seen by those interested in promoting a bilingual education as the return to a monolingual educational ethos, legitimated by the premise that heritage languages should be taught as modern foreign languages within the regular curriculum so as to promote equal opportunities and avoid a segregated education. At the time, the National Council for Mother Tongue Teaching criticised the report because it eschewed the potentialities of a robust bilingual education ${ }^{28}$. The Swann report envisioned the foreign language classroom as a shared space for both the learning of languages (with no distinction between foreign and heritage languages) and the construction of a cohesive British identity, but that did not become a reality. Provision for heritage language education continued to depend on the initiative of each community; and in the few cases where there was indeed curricular integration, classes were attended solely by bilingual students, entailing a "deformation of the official form" ${ }^{29}$. Furthermore, language

${ }^{24}$ Guida de Abreu, Teresa Silva and Hanna Lambert, "Academic achievement of Portuguese children in British schools", in Guida de Abreu, Tony Cline and Hanna Lambert (ed.), The education of Portuguese children in Britain..., cit., p. 8.

${ }^{25}$ Olga Barradas, Portuguese students in London Schools, cit., p. 26.

${ }^{26}$ Gabinete do Secretário de Estado das Comunidades Portuguesas, Relatório da Emigração 2013, Lisboa, Gabinete do Secretário de Estado das Comunidades Portuguesas, 2013, p. 19.

${ }^{27}$ Department of Education and Science, Education for All: The Report of the Committee of Inquiry into the Education of Children from Ethnic Minority Groups (The Swann Report), London, Her Majesty's Stationery Office, 1985.

${ }^{28}$ National Council for Mother Tongue, "The Swann report: Education for all?", Journal of Multilingual and Multicultural Development, 6:6 (1985), p. 497-508.

${ }^{29}$ Hans H. Reich and Ulrike Pörnbacher, "Languages of immigrants as modern foreign languages: a comparative view of the education systems of England, France and (Western) 
learning has struggled to acquire a high profile in the $\mathrm{UK}^{30}$, and a culture of local governance and diversity of provision has traditionally favoured localised partnerships rather than nation-wide projects of language learning ${ }^{31}$.

The 1984 report by the Commission of the European Communities on the implementation of the 1977 directive on the education of children of migrant workers provided a circumspect view of the situation in the United Kingdom. It noted that the system of decentralised governance by Local Education Authorities impeded a comprehensive summary of the measures taken to cater for students with mother tongues other than English, but it also mentioned the existence of support to complementary schools, and the fact that examinations in minority languages counted towards students' qualifications certificates ${ }^{32}$.

In the case of the Portuguese community, heritage language schooling was in a situation of crisis. According to Barradas, a language teacher and researcher in the field of bilingualism and community languages, the needs of students from the Portuguese-speaking community were not being addressed. They were, in her words, "a disappearing act", an invisible population in official documents and statistics ${ }^{33}$. Many Portuguese pupils had a track record of academic underachievement, which was being reinforced by low aspirations and a hostile attitude towards Portuguese language and culture. Furthermore, many schools routinely advised pupils' overworked parents to speak English at home $^{34}$. In her study of the patterns of educational achievement of Portuguese students in Lambeth, Barradas opens the introduction with a personal account

Germany", in International Conference on Maintenance and Loss of Minority Languages, Noordwijkerhout (Netherlands), p. 1-14.

${ }^{30}$ The 2013 Languages for the Future report stresses that the UK lacks the language skills necessary to sustain its economic and cultural position (Teresa Tinsley and Kathryn Board, Languages for the future: which languages the UK needs most and why, British Council, 2013, p. 3).

${ }^{31}$ Philip Woods and Tim Simkins, "Understanding the local: Themes and Issues in the Experience of Structural Reform in England", Educational Management Administration \& Leadership 42:3 (2014), p. 324-340. The tradition of local governance means that nation-wide agreements such as the recent Franco-Portuguese declaration that Portuguese would become part of the offer of modern foreign languages are unlikely (Lusa, "Alunos franceses vão poder aprender português como língua estrangeira”, Público, 2016.07.25). See footnote 78.

${ }^{32}$ Commission of the European Communities, Report from the Commission to the Council on the implementation of directive 77/486/EEC on the education of the children of migrant workers, Brussels, Commission of the European Communities, 1984.

${ }^{33}$ Olga Barradas, “'A disappearing act': Portuguese Students...”, cit., p. 33.

${ }^{34}$ Idem, ibidem; Guida de Abreu, Teresa Silva and Hanna Lambert, "Academic achievement of Portuguese children in British schools", cit.; and Feyisa Demie, "Ethnic and gender differences 
of her first impressions as a heritage language teacher in London in the mid-1980s. Teachers worked with mixed proficiency and multi-age classes, did not follow an established curriculum, had little access to classroom resources, and, in most cases, did not have any contact with mainstream schooling teachers. Learners would not progress if teachers considered that their Portuguese was not appropriate, and heritage languages lessons, especially for older learners, "seemed to drain their last drop of energy at the end of the day"35.

In 1978, the syllabus was based on the principle of equivalence to the Portuguese national curriculum and it closely adhered to content drawn from Portuguese (first language), geography and history ${ }^{36}$. Although it was proving unsuitable, the syllabus was in line with families' expectations of returning to Portugal and children having to integrate into the school system ${ }^{37}$. To remedy the situation, the Ministry of Education released experimental documents: a guide on how to explore literary texts for advanced students, a draft of a curriculum for primary pupils, and, in 1994, a syllabus with content for five years of schooling, from age 6 to $10^{38}$. The latter claimed to be a flexible instrument underpinned by a commitment to a function-based and communicative language learning approach and a multicultural education. It targeted both heritage language and modern foreign language contexts, took into account multi-age and multi-level classes, and advocated a focus on oracy for young learners. In practice, while teachers welcomed most of the changes, some, such as the exclusive focus on speaking, did not make sense and were not strictly adhered to in the UK, where children start schooling in literacy at the age of five ${ }^{39}$.

In Portugal, the post-revolutionary promotion of support mechanisms to diasporic communities was followed by criticism of how the expansion of the network was being managed. While the first programmes for government

in educational achievement and implications for school improvement strategies", Educational Research, 43:1 (2001), p. 91-106.

${ }^{35}$ Olga Barradas, Portuguese students in London Schools, cit., p. 13-15.

${ }^{36}$ José Filipe Pinto, Estratégias da ou para a Lusofonia?, Lisboa, Prefácio, 2009, p. 164.

${ }^{37}$ Olga Barradas, "Learning Portuguese: a tale of two worlds", in Jean Conteh, Peter Martin and Leena Helavaara Robertson (ed.), Multilingual learning: stories from schools and communities in Britain, Stoke on Trent (UK) and Sterling (US), Trentham Books, 2007, p. 89.

${ }^{38}$ Serviços de Ensino Básico - Português no Estrangeiro, Português Ensino Secundário: Apoio Didáctico, Lisboa, Ministério da Educação e Ciência - Instituto de Cultura e Língua Portuguesa, 1980; idem, Projecto do programa de Língua e Cultura Portuguesa: 3 primeiras unidades, Lisboa, Ministério da Educação e Ciência - Instituto de Cultura e Língua Portuguesa, 1982; and Maria Fernanda Antunes, Marina Ribeiro Silva and Matilde Teixeira, Programa de Lingua e Cultura Portuguesas, Lisboa, Departamento da Educação Básica, 1994.

${ }^{39}$ Olga Barradas, "Learning Portuguese: a tale of two worlds", cit., p. 90. 
were unequivocal in their support of the scheme ${ }^{40}$, later programmes included a general commitment to support emigrant communities and a call for a reform of the system. In 1987, the eleventh constitutional government, the first that would complete a full term of office since the revolution (1987-1991), committed to a continuing support of Portuguese migrants on the assumption that such support should be underpinned by a restructuring of the network and a promotion of the language as curricular option abroad ${ }^{41}$. In 1990, Luís Geraldes, a parliament member of the party in government argued that the country should redefine its language policy. The argument was that authorities should strengthen Portuguese as a cultured and historically relevant language spoken by 200 million people, rather than perpetuate its status as an emigrant language. Mr Geraldes called for a re-evaluation of the network of heritage language teaching, which had allegedly been built on good intentions, but was being impaired by poor planning and implementation, and an unbalanced geographical distribution of courses $^{42}$. The qualifications of the teachers and the quality of the pedagogical provision were also under scrutiny, along with the philosophy underlying staff recruitment, whether one of temporary service, privileging an up-to-date knowledge of contemporary Portuguese culture, or one of immersion in local life with a focus on the needs and characteristics of the community ${ }^{43}$.

\section{Addressing the invisibility of a community}

In 2002 there were more than 2,900 students and 35 teachers $^{44}$. By the mid-2010s, the UK had become the main destination for Portuguese migrants, with the arrival of more than 30,000 individuals between 2013 and $2014^{45}$. The proportion of migrants with higher qualifications increased, and in $2011,38 \%$

${ }^{40}$ II Governo Constitucional, Programa do II Governo Constitucional, Lisboa, Governo da República Portuguesa, 1978 (http://www.portugal.gov.pt/media/464015/GC02.pdf, accessed on 2014.04.20).

${ }^{41}$ XI Governo Constitucional, Programa do XI Governo Constitucional, Lisboa, Governo da República Portuguesa, 1987 (http://www.portugal.gov.pt/media/464039/GC11.pdf, accessed on 2014.04.20).

${ }_{42}$ Assembleia da República, Diário da Assembleia da República, Série I, V Legislatura, Sessão legislativa 3, Lisboa, Imprensa Nacional-Casa da Moeda, 1990.

${ }^{43}$ Assembleia da República, Diário da Assembleia da República, Série I, V Legislatura, Sessão legislativa 3, Lisboa, Imprensa Nacional-Casa da Moeda, 1990.

${ }^{44}$ Maria Amélia Estrela, Rosa Starr and Maria Lúmen Rodrigues, "The Portuguese Education Department in the United Kingdom”, cit., p. 202.

${ }^{45}$ Rui Pena Pires et al., Portuguese emigration factbook 2015, Lisbon, Observatório da Emigraç̃o, 2016, p. 16. 
of Portuguese-born migrants aged 15 and over were educated at university level ${ }^{46}$. In spite of a different demographics, the introduction of a fee in 2013 and a period of irregularity between the second half of the 2000s and the first half of the $2010 \mathrm{~s}^{47}$, there was a continued interest in language courses as there were 3,416 students and 23 teachers by the end of the 2015/2016 academic year. Around a third of the students in the 2014-2016 period were accounted for as attending curricular classes. With the exception of a few cases of curricular heritage language classes, the administrative designation implied a strong involvement of the host British school, rather than Portuguese being an actual curricular option. However, it suggested that schools were developing a renewed interest in the promotion of a bilingual education.

In the early 2000s, practitioners, researchers, and authorities looked back on the situation of the previous decades, which prompted remedial action in schools, and a number of scholarly studies.

The call for action was felt in areas where Portuguese migrants settled. The Lambeth authority in South London, an area with a sizeable Portuguese community, acted upon anecdotal evidence that Portuguese students were underachieving and started to monitor the academic performance of newly-arrived Portuguese pupils ${ }^{48}$. The local authority used performance data to identify intervention strategies, provided training to teachers and head teachers, and offered school-based support to families. In addition, it recruited Portuguese advisory teachers and set up links with a Portuguese school ${ }^{49}$. At school level, the commitment of senior management to inclusion, the promotion of targeted support and parental engagement, the recruitment of a diverse workforce, and the celebration of migrants' cultural heritage were deemed instrumental in raising the achievement of Portuguese students ${ }^{50}$.

In 2008, the Lambeth authority released a Portuguese language scheme of work for Key Stage 2 (a lesson-by-lesson programme for the teaching of Portuguese $)^{51}$. It was a way to capitalise the existing work with bilingual

\footnotetext{
${ }^{46}$ Rui Pena Pires et al., Portuguese emigration factbook 2015, cit., p. 11-14.

${ }^{47}$ In 2005 there were 2,250 students (Mário Filipe da Silva, Promoção da Língua Portuguesa no Mundo: Hipótese de Modelo Estratégico, PhD thesis, Universidade Aberta, 2005).

${ }^{48}$ Feyisa Demie, "Ethnic and gender differences in educational achievement...", cit.

${ }^{49}$ Feyisa Demie and Kirstin Lewis, Raising the Achievement of Portuguese Pupils: Good Practice in Lambeth Schools, London, Lambeth Research and Statistics Unit and Lambeth Children and Young People's Service, 2008, p. 39-48.

${ }^{50}$ Idem, ibidem, p. 56-58.

${ }^{51}$ Key Stage 1 (Years 1 and 2, pupils aged 5 to 7); Key Stage 2 (Years 3 to 6, pupils aged 7 to 11); Key Stage 3 (Years 7 to 9, pupils aged 11 to 14); Key Stage 4 (Years 10 to 11, pupils aged 14 to 16$)$.
} 
students $^{52}$ in devising a response to the Independent Review of the Primary Curriculum's recommendation that primary pupils learn one or two foreign languages $^{53}$. A 2016 report by the Lambeth authority, while still pointing out to the underachievement of Portuguese students in the Lambeth area, identified a trend of improvement in performance in Key Stages 1 to 4 between 2009 and $2015^{54}$.

The study by Barradas ${ }^{55}$ exemplifies the need to understand and act upon the problems felt by young Portuguese migrants. The study examined the patterns of academic achievement of students and established that complementary language education functioned both as an extra-linguistic input benefiting the overall school performance of learners, and as a pivotal point for the development of networks of support and a strong cultural identity that could facilitate social inclusion. The main finding was that pupils attending Portuguese classes achieved higher academic results than those who did not attend classes $(41 \%$ in the first group achieved top A-C marks in national exams against $8 \%$ in the second group) ${ }^{56}$.

Another example is Abreu and Lambert's report on the education of Portuguese students commissioned by the Portuguese Ministry of Education (elementary education division) ${ }^{57}$. According to the report, the proportion of Portuguese-speaking children achieving National Curriculum target standards tended to be below local and country-wide averages. The report recommended that British schools and the department of Portuguese education forge close partnerships to develop bilingualism as a way to enhance the students' academic and personal achievements. The same team had organised a conference in

${ }^{52}$ Luísa Ribeiro and Anne Farren, The Key Stage 2 Schemes of Work for Portuguese, London, Children and Young People's Service, London Borough of Lambeth, 2008.

${ }^{53}$ Department for Children Schools and Families, The Independent Review of the Primary Curriculum: Interim report, London, Department for Children, Schools and Families, 2008.

${ }^{54}$ Feyisa Demie et al., The Achievement of Portuguese Pupils in Lambeth Schools - Empirical Evidence 2015, London, Research and Statistics Unit and Lambeth Children \& Young People's Service, 2016. A 2015 study on students attending English as an Additional Language (that is, recently arrived astudents) argued that lower-achieving minority-background students (including Portuguese-speaking pupils) have high levels of economic deprivation (Steve Strand, lars Malmberg and James Hall, English as an Additional Language (EAL) and educational achievement in England: an analysis of the National Pupil Database, Oxford, University of Oxford, 2015).

${ }^{55}$ Olga Barradas, Portuguese students in London Schools, cit.

${ }^{56}$ Olga Barradas, Portuguese students in London Schools, cit., p. 311.

${ }^{57}$ Guida de Abreu and Hanna Lambert, Final Report of the Project: The Education of Portuguese students in England and Channel Islands Schools, Luton, Department of Psychology, University of Luton, 2003. 
2001 , bringing together disperse examples of research and good practice. The leitmotif of the conference and the obstacle to overcome was the invisibility of the community, whose needs were not being addressed in a systematic way ${ }^{58}$.

The Lambeth project did not reflect the overall situation. The language classroom did not become the shared space for foreign language learning and the construction of a British national identity envisaged by the Swann report. However, the report cemented community languages as part of the range of examinations on offer. The report and the implementation of the National Curriculum from 1988 onwards ${ }^{59}$ gave way to the inclusion of Portuguese in an official list of modern foreign languages that could be taught at Key Stage 3 and 4, and incentivised awarding bodies to offer Portuguese language GCSE and A Level examinations to school pupils ${ }^{60}$. Between 1992 and $2015^{61}$, the annual number of pupils sitting Portuguese exams increased eight-fold, from 444 to 3475 . Most students taking up Portuguese exams are heritage language speakers ${ }^{62}$ who want to enrich their GCSE and A-Level portfolios, and enhance their chances of entering their desired university degree. This phenomenon has prompted Higher Education institutions to offer modules for advanced and heritage language learners that want to study Portuguese at university level (Cardiff University, Queen's University Belfast, University of Essex, University of Cambridge and, from 2017-18 onwards, Queen Mary University of London).

Hardly half a decade had elapsed since her 2004 study, when Barradas provided a more optimistic overview of the situation, along with the consideration of future challenges ${ }^{63}$. The picture was now of an established

${ }^{58}$ Guida de Abreu, Tony Cline and Hanna Lambert (ed.), The education of Portuguese children in Britain..., cit., p. 1-6.

${ }^{59}$ Department of Education and Science, The Education (National Curriculum) Modern Foreign Languages) Order, London, HMSO, 1989.

${ }^{60}$ At the end of their compulsory education (Year 11) sit their General Certificate of Secondary Education exams; Advanced Level examination target students completing their post-compulsory education (Years 12 and 13).

${ }^{61}$ Data provided by the House of Commons, the Joint Council for Qualifications, the Office of Qualifications and Examinations Regulation and the Oxford Cambridge and RSA Examinations.

${ }^{62}$ Teresa Tinsley, Languages: the state of the nation, demand and supply of language skills, London, British Academy \& Alcantara Communications, 2013, p. 39-40.

${ }^{63}$ Olga Barradas, "Learning Portuguese: a tale of two worlds", cit.; idem, "Linking community and mainstream schools...", cit.; and Olga Barradas and Yangguang Chen, "How Portuguese and Chinese community schools support educational achievement", in Charmian Kenner and Tina Hickey, Multilingual Europe: Diversity and Learning, Stoke on Trent (UK) and Sterling (USA), Trentham Books, 2008. 
community renewed by the influx of qualified migrants that held Portuguese complementary classes not just as a way of maintaining a link to their heritage (communications and easier travel made that a daily reality) ${ }^{64}$, but as a cultural and academic investment, which had its roots in the high value first generation migrants with lower qualifications assigned to educational opportunities ${ }^{65}$. However, the needs of these different generations of migrants might not be the same. Indeed, in 2007, Barradas called for a re-evaluation of how education systems respond to the needs of bilingual children in an evolving socio-political landscape ${ }^{66}$.

Malyn Newitt, in his history of Portuguese migration, argues that the Portuguese community in the UK is presently divided into a cultural/economic elite and a larger group of poorer and unskilled workers ${ }^{67}$, which is part of contemporary migration trends, especially in global cities like London ${ }^{68}$. However, the socio-cultural make of the Portuguese community is arguably more complex as it includes long-established residents (usually self-employed or business owners), recently arrived migrants who took up low-wage manual employment (cleaning, catering, building, agriculture and food processing industries), and highly qualified professionals working in management, banking, higher education and the arts ${ }^{69}$. While the latter group does not rely on the informal support networks of established Portuguese-speaking residents ${ }^{70}$, an initiative such as the Native Scientist social enterprise, which promotes Portuguese-language science outreach activities in schools by Portuguese researchers working and studying in the UK, suggests that exchanges between the different groups of migrants might be rather common.

${ }^{64}$ Indeed, one of the unifying traits of the Portuguese-speaking community is the maintenance of very close cultural and family ties with Portugal. See José Carlos Pina Almeida and David Corkill, "Portuguese Migrant Workers in the UK: A Case Study of Thetford, Norfolk", Portuguese Studies, 26:1 (2010), p. 27-40.

${ }^{65}$ Olga Barradas, "Linking community and mainstream schools...", cit., p. 136-137.

${ }^{66}$ Olga Barradas, "Learning Portuguese: a tale of two worlds", cit., p. 102.

${ }^{67}$ Malyn Newitt, Emigration and the Sea: An Alternative History of Portugal and the Portuguese, London, Hurst \& Company, 2015, p. 167.

${ }^{68}$ João Peixoto, As migrações dos quadros altamente qualificados em Portugal, $\mathrm{PhD}$ thesis, Universidade Técnica de Lisboa - Instituto Superior de Economia e Gestão, 1998, p. 195-197.

${ }^{69}$ José Carlos Pina Almeida, "Migration and Citizenship of the Portuguese in the UK", Portuguese Studies, 23:2 (2007), p. 208-229.

${ }^{70}$ Maria-João Melo Nogueira, David Porteous and Sandra Guerreiro, The Portuguese-speaking community in Lambeth: a scoping study, London, London Community Foundation, 2015, p. 5-6. 
In 2010, Barradas saw the governmental directive on the responsibility of schools to promote social cohesion ${ }^{71}$ as an opportunity to strengthen bilingual identities. She called for the promotion of a richer multicultural curriculum, an outcome-based approach, and the creation of effective links between schools and communities ${ }^{72}$. In her view, the complementary language classes offered by Portuguese authorities had a measurable impact on students' academic success, and had a yet-to-realise potential as effective intermediaries between mainstream schools and families ${ }^{73}$.

\section{Instituto Camões}

In 2009, the government transferred the supervision of the network of complementary education from the Ministry of Education to the Instituto Camões ${ }^{74}$. The organisation had been created in 1992 to enhance the status of Portuguese as an international means of communication, and to promote its adoption as a foreign language in curricula in other countries. The passing on of responsibilities had been rehearsed in 1995 but organisational and funding issues prevented the administrative change ${ }^{75}$, which would happen in 2009 , backed up by the 2007/2008 restructuring of the institute. According to the 2007/2008 resolutions, the funding and pedagogical supervision of complementary language courses for children and teenagers and the support to Higher Education courses - the traditional area of actuation of the organisation and its institutional predecessors - were to be supervised by a single organisation under a guiding principle of language promotion abroad ${ }^{76}$.

This had been a goal articulated in both media outlets and academic production. In a 2005 opinion piece, Público journalist São José Almeida criticised Durão Barroso's government for abandoning a policy of integration

${ }^{71}$ Department for Children, Skills and Families, Guidance on the duty to promote community cohesion, Nottingham, Department for Children, Schools and Families Publications, 2007.

${ }^{72}$ Olga Barradas, "Linking community and mainstream schools...", cit.

${ }^{73}$ Olga Barradas, "Linking community and mainstream schools...", cit., p. 139-147.

${ }^{74}$ Ministério dos Negócios Estrangeiros, "Decreto-Lei n. ${ }^{\circ}$ 165-C/2009", in Diário da República, $1 .^{\text {a }}$ série, n. ${ }^{\circ}$ 144, Lisboa, Imprensa Nacional-Casa da Moeda.

${ }^{75}$ Assembleia da República, "Decreto-Lei n. ${ }^{\circ}$ 52/95", in Diário da República, n. ${ }^{\circ}$ 67/95, Série I-A de 1995-03-20, Lisboa, Imprensa Nacional-Casa da Moeda and Mário Filipe da Silva, Promoção da Língua Portuguesa no Mundo..., cit., p. 158-159.

${ }^{76}$ Ministério dos Negócios Estrangeiros, "Decreto-Lei n. ${ }^{\circ} 119 / 2007 ”$, in Diário da República, 1. ${ }^{a}$ série, ${ }^{\circ}{ }^{\circ}$ 82. Lisboa, Imprensa Nacional-Casa da Moeda and Presidência do Conselho de Ministros, "Resolucão do Conselho de Ministros n. ${ }^{\circ} 188 / 2008$ ", in Diário da República, $1 .{ }^{\text {a }}$ série, n. ${ }^{\circ} 231,27$ Nov. 2008, Lisboa, Imprensa Nacional-Casa da Moeda. 
of complementary education into educational systems abroad as a modern foreign language, and, implicitly, endorsing a "xenophobe" view of Portuguese language education as the remit of migrant communities ${ }^{77}$. Elsewhere, an attendant view was articulated by Mário Filipe da Silva, who worked with the institute from 1998 onwards, and acted as vice-president from 2010 to 2012. In his 2005 doctorate thesis, he expressed an astringent criticism of the network of complementary education, which he portrayed as a mechanism that circumscribed Portuguese to isolated communities of migrants, preventing its development as a world language ${ }^{78}$.

The 2009 act responded to such criticism by portraying Portuguese as an international language that should be adopted as a subject in educational systems across the world, an expectation that had been in place since 1977. The language was to be the visible face of an underlying cultural, geostrategic, and economic momentum ${ }^{79}$. The network of complementary education was to become an instrument of a far-reaching policy aimed at enhancing the cultural, economic, and geostrategic importance of the Portuguese language ${ }^{80}$, based on the tenets of accountability and efficiency ${ }^{81}$.

In some sense, the reform was going in the opposite direction to what was happening in the UK, amidst the community of researchers and educators, where complementary education was being reassessed as an integral part of a thorough bilingual education. For example, Barradas's 2004 study of the educational achievement of Portuguese-speaking pupils suggested that complementary language schooling had an emancipatory effect in pupils' lives. According to Barradas, the transference of cognitive skills facilitated the creation of higher academic expectations, and enhanced the opportunities to build up social

${ }^{77}$ São José Almeida, "Nível zero", Público, 2005.04.09.

${ }^{78}$ Mário Filipe da Silva, Promoção da Língua Portuguesa no Mundo..., cit., p. 126. As recently as 2014, in a meeting with British counterpart Michael Gove, former Portuguese Minister of Education Nuno Crato put forward a governmental partnership for the promotion of Portuguese as a foreign language as a subject in British schools. According to the minister, the move would enhance the profile of the language and help children of Portuguese descent. The meeting was held in the context of the World Education Forum (Lusa, "Nuno Crato quer professores nas escolas inglesas para promover o português", Público, 2014.01.21). See footnote 31.

${ }^{79}$ Ministério dos Negócios Estrangeiros, "Decreto-Lei n. ${ }^{\circ} 165-\mathrm{C} / 2009 "$, cit., p. 2-12.

${ }^{80}$ Ministério dos Negócios Estrangeiros, “Decreto-Lei n. ${ }^{\circ}$ 165-C/2009”, cit., p. 12.

${ }^{81}$ See Clara Keating, Olga Solovova and Olga Barradas, "Migrations, Multilingualism and Language Policies in Portugal and the United Kingdom: A Polycentric Approach", in Luiz Moita-Lopes, Global Portuguese: linguistic ideologies in late modernity, New York and London, Routledge, p. 156-158. 
capita ${ }^{82}$. Keating, Solovova and Barradas, in a study that contrasts the values associated with the Portuguese language in two different communities (the sphere of public policy in Portugal and the migrant community in the UK), have argued that the reform of the network of complementary education impacted school life with restrictions on pedagogical practices that could take into account and build upon students' multilingual patterns of behaviour ${ }^{83}$. The argument was that official policy was replacing the specific cultural and emotional values pertaining to a context-sensitive language education with a generalist foreign language education.

In 2009, the Ministry of Education (which shared the pedagogic supervision of the network with the Ministry of Foreign Affairs) introduced the Common European Framework of Reference for Languages (CEFRL) as the basis for a degree of standardisation oversight over different contexts ${ }^{84}$. The CEFRL had been created in 2001 by the Council of Europe to serve as a basis for the development of syllabi and pedagogical resources. The document described standards of linguistic knowledge and skills for any language or context. 2009 saw the introduction of a statutory specification, the CEFRL-compliant Quadro de Referência para o Ensino Português no Estrangeiro (QuaREPE), which aimed at providing guidance to community language courses, modern foreign language classes, and bilingual education contexts ${ }^{85}$. Centrally, the institute supported the publication of course books for young learners, and created an ALTE-certified ${ }^{86}$ examination and qualifications scheme for children and teenagers based on QuaREPE and CEFRL ${ }^{87}$. These resources have been seen as instruments in the realignment of the network of complementary courses, catering to a varied audience of foreign language pupils and heritage

${ }^{82}$ Olga Barradas, Portuguese students in London Schools, cit., p. 326-327.

${ }^{83}$ Clara Keating, Olga Solovova and Olga Barradas, "Migrations, Multilingualism...,", cit.

${ }^{84}$ Ministério da Educação, "Portaria n. ${ }^{0}$ 914/2009", in Diário da República, 1. a série, n. ${ }^{\circ} 158$, de 17 de Agosto de 2009, Lisboa, Imprensa Nacional-Casa da Moeda.

${ }^{85}$ Maria José Grosso, António Soares, Fernanda de Sousa and José Pascoal, Quadro de Referência para o Ensino Português no Estrangeiro, Ministério da Educação/DGIDC, 2011, p. 6.

${ }^{86}$ Association of Language Testers in Europe.

${ }^{87}$ See Instituto Camões, "Certificação EPE - o que deve saber", Centro Virtual Camões/ Instituto Camões (2016) (http://cvc.instituto-camoes.pt/certificacao-epe/certificacao-epe-o-que-deve-saber.htm, accessed on 2016.09.24), and Mário Filipe da Silva, "Qualificação do ensino português no estrangeiro e difusão da língua portuguesa", in Seminário/Webinário, Política de Língua, Planeamento Linguístico e Mudança Social, Homenagem a Robert L. Cooper, Lisboa, Universidade Aberta, 2013, p. 1-9. 
learners ${ }^{88}$, who allegedly hold an ever-increasing distant relationship with the Portuguese language ${ }^{89}$.

Whether classroom practice and behaviour in complementary schools provides a counterpoint to official policy is a question open to debate. Barradas and Souza inform that the language maintenance principle of Brazilian complementary schools in the UK replicate a monolingual ethos prevalent in Brazil, which tends to promote a clear separation between Portuguese and English ${ }^{90}$. However, classrooms have been shown to allow learners the exploration of multilingual identities and the rehearsal of purposeful language choices, which suggests that classroom practices devise feasible forms of language policy relative to context and official policy ${ }^{91}$. Despite the Brazilian example, Keating, Solovova and Barradas's criticism is valid in that the reform has brought about the need to ensure that the network provided benchmarked outcomes in line with internationally recognised standards drawn from the field of modern foreign language education - and not outcomes grounded in the specific needs of the community.

\section{Conclusion}

The network of complementary education supervised by the Instituto Camões began as a grassroots initiative, underpinned by a language maintenance rationale and strong parental involvement. Soon after the 1974 democratic revolution, a conflict ensued between the values endorsed by the community in respect to the network of complementary education and a policy of language spread abroad emanating from the instances of political power in Portugal, the Portuguese government, the Ministry of Education and the Ministry of Foreign Affairs/Instituto Camões.

Amidst the community, the language maintenance policy of the earliest courses gave way to complementary language schooling being considered as an investment in cultural and educational capital. This happened as a result of the historical evolution of the Portuguese community in the UK. In the wake of the problems felt by Portuguese-speaking students in the 1980s and 90s, educators and researchers actively sought to rehabilitate complementary schooling as an

${ }^{88}$ See Instituto Camões, Ensino Português no Estrangeiro: Programa Nível A1, Lisboa, Direção de Serviços de Língua e Cultura, 2012, p. 2.

${ }^{89}$ Mário Filipe da Silva, "Qualificação do ensino português...", cit. p. 2-3.

${ }^{90}$ Olga Barradas and Ana Souza, "Português como Língua de Herança: Políticas Linguísticas na Inglaterra”, Revista SIPLE, 4, 2014.

${ }^{91}$ Ana Souza, "Language choice and identity negotiations in a Brazilian Portuguese community school”, in Vally Lytra and Peter Martin (ed.), Sites of Multilingualism..., cit., p. 97-107. 
emancipatory and integral component of the education of bilingual students, and as a key instrument in preventing poor academic achievement. The Portuguese language examinations offered by the British educational system, a legacy of the favourable conditions created by the Swann report and the National Curriculum, offered students a practical way to build upon their skills and academic work.

Elsewhere, Portuguese as a community language threatened the make of a projected instrument of global communication. Political, media and academic discourses in Portugal portrayed complementary education abroad as a parochial constraint on the economic and geopolitical potential of the Portuguese language and Portugal itself, as the country was reinventing its standing in the world stage as a member of the European Union. The principled negative stance on complementary education and the issues of concern about the quality of management and pedagogical provision defaulted into a policy of repurposing the network of complementary education to enhance the profile of Portuguese as a modern foreign language.

The expectation that Portuguese should become part of foreign curricula had been in the works since 1977, but it was in the mid to late 2000s that the Ministry of Education and then the Instituto Camões adopted a more explicit policy for the promotion of Portuguese broad as a modern foreign language. However, where Portuguese is offered as a curricular option, it is mostly taught as a heritage language rather than as a modern foreign language on a par with French or Spanish. The situation is reminiscent of how the Swann report and the National Curriculum failed to combine community language and foreign language learning. Despite their differing aims, managing multiculturalism in the British case, and an attempt to further an agenda of language spread abroad in the Portuguese case, both policies followed a similar approach. The instruments used in combining community and modern language learning (the GCSE/A-Level and CEFRL-inspired examinations schemes, and the official status of curricular option) could not counteract an adverse scenario of lack of demand for foreign languages and a tradition of localised governance.

The community of learners, parents and educators seized the instruments offered by the British education system and the Portuguese policy of language spread abroad to build up social and cultural capital (and the attendant social mobility), undeterred by their foreign language underpinnings and the shift into a generic language education. This suggests that there is scope for ethnographic research investigating how interactions in the complementary school classroom create further layers of Portuguese language policy where the contingency of a multilingual audience gives shape to unscripted forms of articulation between official language policies and viable forms of language education. 